\title{
Effects of Surfactant Lipids and Surfactant Protein A on Host Defense Functions of Rat Alveolar Macrophages
}

\author{
ANNMARIE GOLIOTO AND JO RAE WRIGHT \\ Neonatal-Perinatal Research Institute [A.G., J.R.W.], Departments of Pediatrics [A.G.] and Cell Biology \\ [J.R.W.], Duke University Medical Center, Durham, North Carolina 27710, U.S.A.
}

\begin{abstract}
ABST
Survanta is commonly used as replacement therapy in new-
born infants suffering from surfactant deficiency. We investi-
gated the effects of Survanta and surfactant-like liposomes in the
presence and absence of surfactant protein A (SP-A) on host
defense functions of rat alveolar macrophages (AM). Phagocy-
tosis of Streptococcus pneumoniae by AM was significantly
inhibited in the presence of $100 \mu \mathrm{g} / \mathrm{mL}$ of Survanta. The ability
of SP-A to enhance phagocytosis of S. pneumoniae was signif-
icantly compromised upon exposure to either Survanta or lipo-
somes, although the overall level of phagocytosis remained
higher than in the absence of SP-A. This inhibitory effect was not
overcome by opsonization of the bacteria with SP-A before
incubation with Survanta and AM. We also found that the ability
of SP-A to mediate the association of group B Streptococcus
with AM was compromised to a significant degree when exposed
to either Survanta or liposomes in concentrations of 150 and 250
\end{abstract}
RDS, a frequent complication of prematurity in neonates, is due to a deficiency in surfactant, a lipoprotein complex responsible for decreasing surface tension in alveoli (1). Over the last two decades, it has become the standard of care to provide surfactant replacement therapy for RDS since Fujiwara et al. (2) reported the successful treatment of human neonates with artificial surfactant. Although natural surfactant consists mainly of phospholipids, neutral lipids, and at least four proteins designated A, B, C, and D, surfactant replacement therapies in use today consist primarily of phospholipids and, in some cases, surfactant proteins B and C.

SP-A is synthesized by alveolar type II cells and Clara cells (3) and is the most abundant surfactant protein. It is not found in currently available commercial surfactant replacement ther-

Received March 5, 2001; accepted October 19, 2001.

Correspondence and reprint requests: Jo Rae Wright, Ph.D., Box 3709, Department of Cell Biology, Duke University Medical Center, Durham, NC 27710, U.S.A.; e-mail: J.Wright@cellbio.duke.edu

Supported by National Institutes of Health, National Research Service Award HL07538 and RO1 HL-51134 from the National Heart, Lung and Blood Institute.

An abstract pertaining to this work was presented in a poster session at the Society for Pediatric Research Meeting, Baltimore, MD, U.S.A., April-May 2001. $\mu \mathrm{g} / \mathrm{mL}$. However, at most concentrations of Survanta or liposomes tested, the presence of SP-A resulted in significantly higher levels of bacterial association. These data show that Survanta and surfactant-like lipids suppress host defense functions of AM in the presence and absence of SP-A in vitro, although SP-A continues to enhance host defense functions overall. (Pediatr Res 51: 220-227, 2002)
SP-A, surfactant protein A
FACS, fluorescent activated cell sorter
GBS, group B Streptococcus
AM, alveolar macrophage(s)
RDS, respiratory distress syndrome
DPBS, Dulbecco's PBS

\section{Abbreviations}

apies. Mice made SP-A deficient by homologous recombination have relatively normal pulmonary function; therefore, it appears SP-A is not essential to achieve the surface tensionlowering properties of surfactant (4). Rather, SP-A is an important mediator of the innate immune system and has been shown to influence host defense functions of AM (5-12). In addition, SP-A-deficient mice display an increased susceptibility to infection (13) and inflammation (14). Recently it has been reported that bacterial phagocytosis by AM in vivo can be augmented in SP-A-deficient mice by treating the mice with exogenous SP-A (5).

Phagocytic activities of AM help defend the alveoli against infection (15), and AM have been identified in the airways and alveoli of infants dying from bacterial pneumonia (16). This important population of cells begins increasing just before birth (17) and continues to accumulate rapidly over the hours and days after birth (18-20). AM have been demonstrated to avidly ingest phospholipids $(17,21)$, a property of AM that has been found in conjunction with a decrease in pathogen killing (22, 23). Therefore, it is not surprising that several studies have suggested that treatment with surfactant may impair AM host 
defense mechanisms (22-24). Clinically, it is difficult to distinguish infants with RDS from those suffering from congenital bacterial pneumonia or both disorders concurrently; therefore, some infants treated with surfactant replacement will have active pulmonary infection $(25,26)$. Recently, it has been reported that GBS-infected infants can benefit from surfactant replacement therapy to improve gas exchange; however, their mortality remains high when compared with uninfected surfactant-treated infants (27).

The role of SP-A as an integral component of the innate immune system of the lung has been well described in the literature; however, relatively little is known about how the presence of lipids may affect SP-A-mediated functions. We hypothesized that Survanta, a commonly used surfactant replacement therapy, and surfactant-like liposomes would inhibit host defense functions of AM in the presence and absence of SP-A in vitro. Nonetheless, we propose that the presence of SP-A may be protective against the inhibitory effects Survanta and liposomes exert on AM.

\section{METHODS}

Animals. Male pathogen-free Sprague-Dawley rats (150250 g) were obtained from Charles River Laboratories (Raleigh, NC, U.S.A.) and Taconic Farms (Germantown, NY, U.S.A.). The Institutional Animal Care and Use Committee of Duke University approved the use of animals in this study.

Media and chemicals. DPBS without calcium chloride or magnesium chloride was obtained from GIBCO-BRL (Grand Island, NY, U.S.A.). BSA, fraction $\mathrm{V}$, fatty acid poor, endotoxin-free, was from Calbiochem (La Jolla, CA, U.S.A.). All other chemicals were obtained from Sigma Chemical Co. (St. Louis, MO, U.S.A.) except as noted.

Bacteria. Clinical isolates of Streptococcus pneumoniae and GBS were a generous gift of Dr. Roy Hopfer (Medical Microbiology Laboratory, UNC-CH Medical Center) and the University of North Carolina-Chapel Hill Medical Center. Both Streptococcus species were cultured on TSA-II agar plates containing 5\% sheep blood (Becton-Dickinson Microbiology Systems, Cockeysville, MD, U.S.A.). Bacterial strains were titrated in suspension to correlate an absorbance at $660 \mathrm{~nm}$ to colony-forming units (CFU) per milliliter.

Labeling of bacteria with FITC. Bacteria were transferred $24 \mathrm{~h}$ after streaking from agar plates into $1 \mathrm{~mL}$ of DPBS. The resultant suspension was heated to $95^{\circ} \mathrm{C}$ for 15 min to kill the bacteria. The heat-killed bacteria were then labeled with FITC (Molecular Probes, Eugene, OR, U.S.A.) as previously described (11) with the exception that the final FITC concentration was $0.1 \mathrm{mg} / \mathrm{mL}$. The labeled bacteria were suspended in 1 $\mathrm{mL}$ DPBS, and the absorbance at $660 \mathrm{~nm}$ was measured to estimate final bacterial concentration. Labeled bacteria were stored until use at $-80^{\circ} \mathrm{C}$.

Survanta. Survanta (beractant) is a natural bovine lung extract made up of phospholipids, approximately half of which are dipalmitoylphosphatidylcholine, in addition to neutral lipids, fatty acids, and surfactant proteins. The lipid portion is supplemented to replicate the surface tension-lowering properties of natural surfactant. Survanta contains $25 \mathrm{mg}$ phospho- lipid per milliliter of $0.9 \%$ sodium chloride. Survanta's protein fraction, which is less than $1 \mathrm{mg} / \mathrm{mL}$, is comprised of surfactant proteins $\mathrm{B}$ and $\mathrm{C}$ and does not contain SP-A according to the product information insert. Survanta was generously supplied by Ross Products Division, Abbott Laboratories, Columbus, OH, U.S.A.

Liposome preparation. All lipids were obtained from Avanti Polar Lipids (Alabaster, AL, U.S.A.). Lipids were dried under nitrogen in a round-bottom flask and then resuspended in $0.9 \%$ sodium chloride (Mallinckrodt Baker, Inc., Paris, KY, U.S.A.) to a final concentration of $1 \mathrm{mg}$ phospholipid $/ \mathrm{mL}$. The lipids were incubated at $37^{\circ} \mathrm{C}$ for $1 \mathrm{~h}$ with gentle shaking every 10 min. Mixing was facilitated by the addition of four glass beads to the flask just before incubation. The final liposome composition was $52 \%$ dipalmitoylphosphatidylcholine, $26 \%$ egg phosphatidylcholine, $15 \%$ dipalmitoylphosphatidylglycerol, and $7 \%$ cholesterol by weight. The liposomes were then stored in glass at $4^{\circ} \mathrm{C}$.

Proteins. SP-A was purified from the bronchoalveolar lavage fluid of patients with alveolar proteinosis as previously described (28). SP-A was stored in 2-5 mM Tris-buffered water (ICN Biochemicals, Aurora, OH, U.S.A.) at $-20^{\circ} \mathrm{C}$. Preparations were tested for bacterial endotoxin using a Limulus amebocyte lysate assay (Bio-Whittaker, Walkersville, MD, U.S.A.). All preparations contained $\leq 0.31 \mathrm{pg}$ endotoxin $/ \mu \mathrm{g}$ protein. IgG from human serum (Sigma Chemical Co., St. Louis, MO, U.S.A.) was obtained as a lyophilized powder and reconstituted in saline. C1q from human serum was purchased from Advanced Research Technologies, San Diego, CA, U.S.A. Mannose-binding lectin was isolated from whole rat serum (Pel-Freeze, Rogers, AR, U.S.A.) as previously reported (29). Recombinant rat surfactant protein D (SP-D) was purified after expression in Chinese hamster ovary cells transfected with SP-D cDNA ligated into the pEE14 vector (Celltech Therapeutics, Ltd., Berkshire, UK) as previously described in detail (30).

Binding of SP-A to S. pneumoniae. FITC S. pneumoniae (3.3-4.4 $\left.\times 10^{8} \mathrm{CFU}\right)$ were suspended in $1 \mathrm{~mL}$ phagocytosis buffer [DPBS $+0.9 \mathrm{mM} \mathrm{CaCl}_{2}$ (Mallinckrodt Baker, Inc., Paris, KY, U.S.A.) $+0.1 \%$ BSA] in a microfuge tube. SP-A was added to a final concentration of $25 \mu \mathrm{g} / \mathrm{mL}$. The bacteria and SP-A were incubated for $1 \mathrm{~h}$ in the dark at room temperature on a rotator. The bacteria were then pelleted at maximal speed in a microfuge for $2 \mathrm{~min}$. The bacteria were washed three times by centrifugation in phagocytosis buffer to remove excess SP-A and resuspended to a final concentration of $5 \times 10^{6}$ $\mathrm{CFU} / \mu \mathrm{L}$ for immediate use.

Isolation of AM. Rats were killed by intraperitoneal injection of pentobarbital, and their tracheas were cannulated and lungs removed. Rat lungs were lavaged six times with a solution containing $140 \mathrm{mM}$ sodium chloride, $5 \mathrm{mM} \mathrm{KCl}, 2.5$ $\mathrm{mM} \mathrm{Na} \mathrm{HPO}_{4}, 10 \mathrm{mM}$ HEPES, $0.2 \mathrm{mM}$ EGTA, and $6 \mathrm{mM}$ glucose, $\mathrm{pH} 7.4$, at $37^{\circ} \mathrm{C}$ and twice with a solution containing $140 \mathrm{mM} \mathrm{NaCl}, 5 \mathrm{mM} \mathrm{KCl}, 2.5 \mathrm{mM} \mathrm{Na}_{2} \mathrm{HPO}_{4}, 10 \mathrm{mM}$ HEPES, $6 \mathrm{mM}$ glucose, $2 \mathrm{mM} \mathrm{CaCl}_{2}$, and $1.3 \mathrm{mM} \mathrm{MgSO}_{4}, \mathrm{pH} 7.4$, at $37^{\circ} \mathrm{C}$. The pooled lavage was centrifuged at $228 \times g$ for 10 min at room temperature, and AM were resuspended in phago- 
cytosis buffer to a final concentration of $2 \times 10^{6} / \mathrm{mL}$. AM were $>98 \%$ viable as determined by erythrosin-B exclusion.

Phagocytosis of $S$. pneumoniae by AM. Microfuge tubes were coated with $0.1 \% \mathrm{BSA}$ at $37^{\circ} \mathrm{C}$ for $1 \mathrm{~h}$ and then rinsed twice with deionized and distilled water. Heat-killed FITC $S$. pneumoniae were added to the microfuge tubes to a final ratio of 100 bacteria per AM along with Survanta or liposomes in varying concentrations up to $100 \mu \mathrm{g} / \mathrm{mL}$ in the presence and absence of $25 \mu \mathrm{g} / \mathrm{mL}$ of SP-A. Phagocytosis buffer was used to bring the total volume of each condition to $500 \mu \mathrm{L}$. Survanta, liposomes, and SP-A were added to the extent that the desired concentration would be achieved in the final volume of 500 $\mu \mathrm{L}$. The contents were vortexed for $5 \mathrm{~s}$ before the addition of $5 \times 10^{5}$ macrophages to each sample. The microfuge tubes were then incubated in a heating block at $37^{\circ} \mathrm{C}$ with moderate shaking for $1 \mathrm{~h}$ in the dark, and the assay was completed as described previously (11). Briefly, the cells were washed three times with cold DPBS and split into two sets of samples. One set was resuspended in $0.2 \mathrm{mg}$ of trypan blue per milliliter in $0.02 \mathrm{M} \mathrm{NaC}_{2} \mathrm{H}_{3} \mathrm{O}_{2}, \mathrm{pH} 5.8$, to quench the signal of fluorescent bacteria on the surface of AM. The trypan blue-treated cells were washed three times with DPBS before fixation in $1 \%$ formaldehyde (Mallinckrodt Baker, Inc., Paris, KY, U.S.A.). The other set was fixed in 1\% formaldehyde without treatment with trypan blue. After fixation, all samples were transferred to polystyrene round-bottom tubes (Becton-Dickinson, Franklin Lakes, NJ, U.S.A.) and stored at $4{ }^{\circ} \mathrm{C}$ in the dark until analyzed by FACS. The design of the experiments is such that the detected level of phagocytosis or cell association can vary between experiments but not within an experiment; therefore, controls were consistently repeated for each of the reported studies.

Association of GBS with AM. This assay was performed as above for phagocytosis with the following exceptions: Survanta or liposomes were added in concentrations up to 250 $\mu \mathrm{g} / \mathrm{mL}$, and the assay was terminated before the addition of trypan blue to a paired set of cell samples. We were unable to adequately quench the FITC signal associated with GBS with trypan blue; subsequently, FACS analysis cannot distinguish internalized bacteria from those on the surface of the AM. Therefore, for experiments employing the use of GBS, we report the results as association with AM rather than phagocytosis by AM to account for the possibility of surface-associated bacteria.

FACS analysis. FACS analysis was performed at Duke University Cancer Center. FACS employs the technique of flow cytometry to count cells and is able to distinguish cells with associated fluorescent signal from those without such signal. Approximately 10,000 cells per sample were analyzed for percent FITC-positive cells. A decrease in FITC signal by $65 \%$ or greater between the nontrypan and trypan samples was considered adequate quenching of extracellular fluorescence.

Statistical analysis. The response of the cells, either a change in the rate of phagocytosis or bacterial association with AM, was expressed as a percent of the control condition (set at $100 \%$ ) for a given set of experiments. Data were analyzed using ANOVA and the Tukey test. Results reported represent the mean of at least three experiments with the addition of error bars to indicate the SEM. An asterisk indicates significant results and their corresponding $p$ value.

\section{RESULTS}

Survanta and surfactant-like liposomes inhibit phagocytosis of $S$. pneumoniae by $A M$ in a concentration-dependent manner. We sought to determine whether the presence of Survanta or surfactant-like liposomes would affect the ability of AM to phagocytose $S$. pneumoniae. At the highest concentration tested, $100 \mu \mathrm{g} / \mathrm{mL}$, both Survanta and liposomes decreased phagocytosis from the control (e.g. the condition in which no Survanta or liposomes were present) value of $100 \%$ to $66.8 \pm 6.9 \%(p=0.028)$ and $56 \pm 8.3 \%$, respectively, as determined by FACS analysis (Fig. 1). Phagocytosis steadily returned toward control values in individual samples of AM exposed to decreasing concentrations of Survanta or liposomes. A representative experiment in which phagocytosis is expressed as percent FITC-positive cells is shown in Table 1.

$S P-A$ stimulates phagocytosis of $S$. pneumoniae by $A M$. Prior studies demonstrated that $25 \mu \mathrm{g} / \mathrm{mL}$ human SP-A stim-

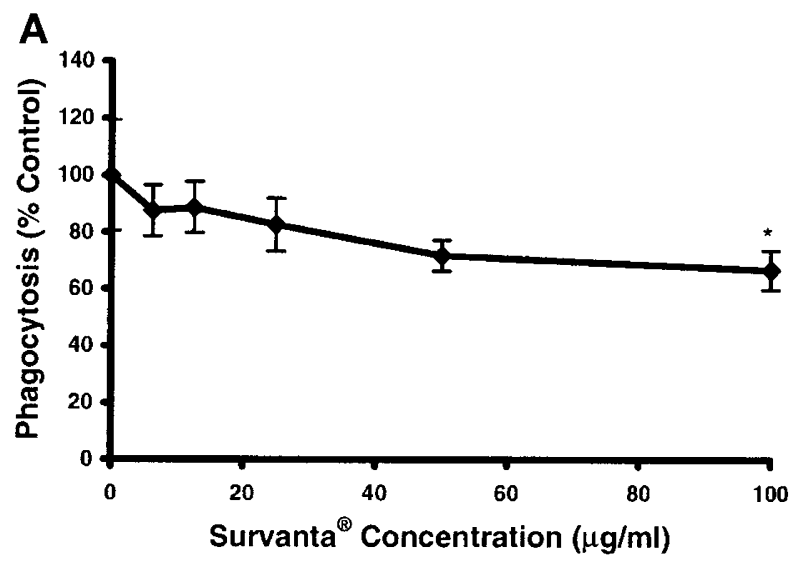

B

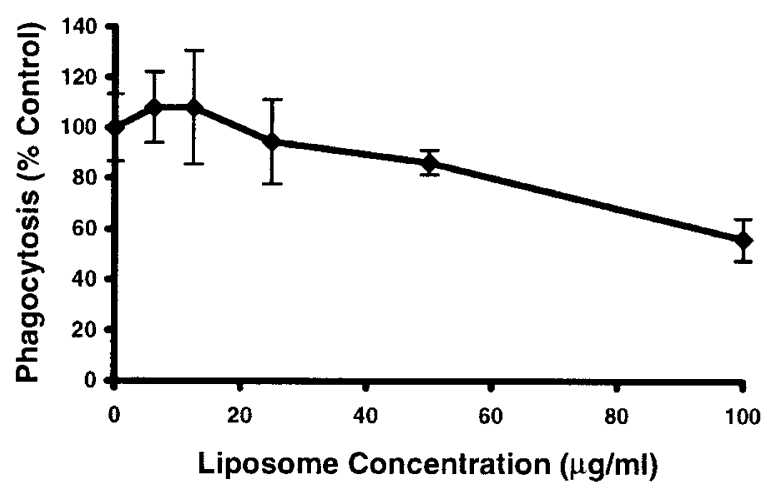

Figure 1. Survanta and surfactant-like liposomes inhibit phagocytosis of $S$. pneumoniae by AM in a concentration-dependent manner. Increasing concentrations of either $(A)$ Survanta or $(B)$ liposomes were incubated with AM and FITC $S$. pneumoniae in DPBS $+0.9 \mathrm{mM} \mathrm{CaCl}_{2}+0.1 \%$ BSA. Fluorescence external to the macrophages was quenched with trypan blue. Phagocytosis was measured by FACS analysis. Data are expressed as a percent of the control condition in which no Survanta or liposomes were added and represent the mean \pm SEM for at least three experiments. *Significantly decreased $(p=$ 0.028) from the control. 
Table 1. Surfactant-like liposomes inhibit phagocytosis of $S$. pneumoniae by AM in the presence and absence of SP-A

\begin{tabular}{|c|c|c|c|c|c|c|}
\hline & \multicolumn{6}{|c|}{ Liposome concentration $(\mu \mathrm{g} / \mathrm{mL})$} \\
\hline No SP-A & $16.5 \%$ & $16.8 \%$ & $13.3 \%$ & $11.9 \%$ & $12.7 \%$ & $7.1 \%$ \\
\hline
\end{tabular}

$\mathrm{AM}$ were incubated at $37^{\circ} \mathrm{C}$ for $1 \mathrm{~h}$ in phagocytosis buffer with FITC S. pneumoniae and varying concentrations of liposomes in the presence and absence of $25 \mu \mathrm{g} / \mathrm{mL}$ of SP-A. Extracellular fluorescence was quenched by the addition of trypan blue. Phagocytosis was measured by FACS analysis. Percentages shown are for FITC-positive cells of one representative experiment.

ulates phagocytosis of $S$. pneumoniae by AM (8). We tested human SP-A, human IgG, human C1q, recombinant rat SP-D, or rat mannose-binding lectin in a phagocytosis assay with $S$. pneumoniae to determine what effect, if any, they would have on the ability of AM to phagocytose bacteria. AM incubated with bacteria alone served as a control. Only SP-A was found to alter phagocytosis significantly from the baseline of $100 \%$ to $276.5 \pm 90.1 \%(p=0.03)$ as determined by FACS analysis (Table 2). Heat treatment of the SP-A abrogated this effect.

Survanta and surfactant-like liposomes inhibit SP-Amediated stimulation of phagocytosis of $S$. pneumoniae by $A M$ in a concentration-dependent manner. We hypothesized that Survanta and/or surfactant-like liposomes would suppress the SP-A-mediated stimulation of phagocytosis. SP-A was unable to maintain the same level of stimulation in the presence of $100 \mu \mathrm{g} / \mathrm{mL}$ of Survanta as well as 50 and $100 \mu \mathrm{g} / \mathrm{mL}$ of liposomes (Fig. 2). SP-A-mediated stimulation of phagocytosis decreased from the control value of $100 \%$ to $43.2 \pm 11 \%(p=$ $0.01)$ at $100 \mu \mathrm{g} / \mathrm{mL}$ of Survanta and $58.2 \pm 6.4 \%(p=0.001)$ at $50 \mu \mathrm{g} / \mathrm{mL}$ of liposomes and $50.9 \pm 4.8 \%(p=0.0003)$ at $100 \mu \mathrm{g} / \mathrm{mL}$ of liposomes as determined by FACS analysis. The ability of SP-A to mediate stimulation of phagocytosis of $S$. pneumoniae approached control values as individual samples of AM were exposed to decreasing concentrations of Survanta or liposomes. A representative experiment in which phagocytosis is expressed as percent FITC-positive cells is shown in Table 1.

The ability of SP-A to stimulate phagocytosis of S. pneumoniae is preserved in the presence of lower concentrations of Survanta and surfactant-like liposomes. It was demonstrated in Figure 2 that SP-A loses its ability to maximally stimulate phagocytosis of $S$. pneumoniae by AM upon exposure to higher concentrations of Survanta and liposomes when compared with SP-A alone. We then compared the degree of phagocytosis achieved in the presence of $25 \mu \mathrm{g} \mathrm{SP}-\mathrm{A} / \mathrm{mL}$ and varying concentrations of Survanta (Table 3) or liposomes (Table 4) to the control condition, which consisted of AM and FITC $S$. pneumoniae only. We found that SP-A was able to significantly increase phagocytosis to $433 \pm 91.4 \%(p=$ $0.005)$ in the absence of Survanta as well as to $411.5 \pm 92.4 \%$ $(p=0.05)$ and $405.2 \pm 82.5 \%(p=0.04)$ in the presence of 6.25 and $12.5 \mu \mathrm{g} / \mathrm{mL}$ Survanta, respectively. In the absence of liposomes, SP-A increased phagocytosis by $302.8 \pm 28.8 \%$ ( $p$ $=0.002)$ over control and retained stimulatory activity of $284.9 \pm 15.4 \%(p=0.003), 286 \pm 25.9 \%(p=0.003)$, and $266.2 \pm 34.1 \%(p=0.007)$ in the presence of $6.25,12.5$, and $25 \mu \mathrm{g} / \mathrm{mL}$ of liposomes, respectively.

Survanta inhibits phagocytosis of SP-A-opsonized S. pneumoniae by $A M$ in a concentration-dependent manner. Previ- ous studies demonstrated that SP-A binds to S. pneumoniae in a concentration- and calcium-dependent manner and acts as an opsonin to enhance phagocytosis (8). To test whether Survanta also inhibited opsonic phagocytosis, FITC $S$. pneumoniae were opsonized with $25 \mu \mathrm{g} / \mathrm{mL}$ SP-A before incubation with varying concentrations of Survanta and AM in phagocytosis buffer in contrast with the previously described experiments in which SP-A was present in solution during the entire incubation period. Significant inhibition remained present at both 50 and $100 \mu \mathrm{g} / \mathrm{mL}$ of Survanta, indicating that prevention of SP-A from binding to $S$. pneumoniae was not the only mechanism by which Survanta was acting (Fig. 3). Compared with the control value of $100 \%$, phagocytosis was significantly decreased to 46 $\pm 10.4 \%(p=0.028)$ and $43.4 \pm 8.3 \%(p=0.018)$ at 50 and $100 \mu \mathrm{g} / \mathrm{mL}$ of Survanta, respectively. The inhibitory effect was no longer detectable as the concentration of Survanta was lowered in individual samples.

Survanta and surfactant-like liposomes inhibit SP-Astimulated association of GBS with AM in a concentrationdependent manner. SP-A has been demonstrated to enhance both phagocytosis and clearance of GBS by AM in the lungs of SP-A-deficient mice (5). We sought to determine what effect Survanta or surfactant-like liposomes would have on the ability of SP-A to stimulate GBS association with AM. As determined by FACS analysis, both Survanta and liposomes in concentrations of 150 and $250 \mu \mathrm{g} / \mathrm{mL}$ were found to significantly inhibit SP-A-stimulated association of bacteria with AM when compared with the control condition in which no Survanta or liposomes were present (Fig. 4). In the case of Survanta, the percentage of cells with associated bacteria decreased from control at $100 \%$ to $58.4 \pm 10.9 \%(p=0.034)$ at $150 \mu \mathrm{g} / \mathrm{mL}$ and $45.2 \pm 12.2 \%(p=0.003)$ at $250 \mu \mathrm{g} / \mathrm{mL}$. Similarly, the

Table 2. SP-A stimulates phagocytosis of $S$. pneumoniae by AM

\begin{tabular}{lc}
\hline Protein & $\%$ Control \\
\hline SP-A & $276.5 \pm 90.1^{*}$ \\
h.i. SP-A & $107.1 \pm 12.5$ \\
IgG & $126.6 \pm 13.8$ \\
C1q & $88.6 \pm 13$ \\
SP-D & $105.5 \pm 14.7$ \\
MBL & $78.4 \pm 12$ \\
\hline
\end{tabular}

Phagocytosis in the absence of added protein served as the control and is set at $100 \%$. Values are expressed as percent of control. AM were incubated at $37^{\circ} \mathrm{C}$ for $1 \mathrm{~h}$ in phagocytosis buffer with FITC S. pneumoniae and one of the following proteins: SP-A, heat inactivated SP-A, IgG, C1q, SP-D, or mannosebinding lectin (MBL). All protein concentrations were $25 \mu \mathrm{g} / \mathrm{mL}$ except rat $\mathrm{SP}-\mathrm{D}$, which was $1 \mu \mathrm{g} / \mathrm{mL}$. Extracellular fluorescence was quenched by trypan blue. Phagocytosis was measured by FACS analysis. Results represent the mean $\pm \mathrm{SE}$ for four experiments. * Significantly greater than control $(\mathrm{p}=$ 0.03 ). 


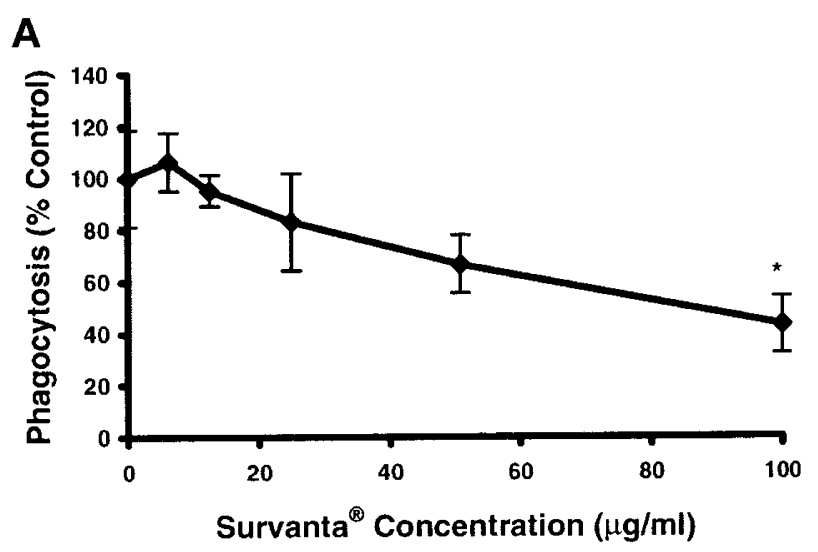

B

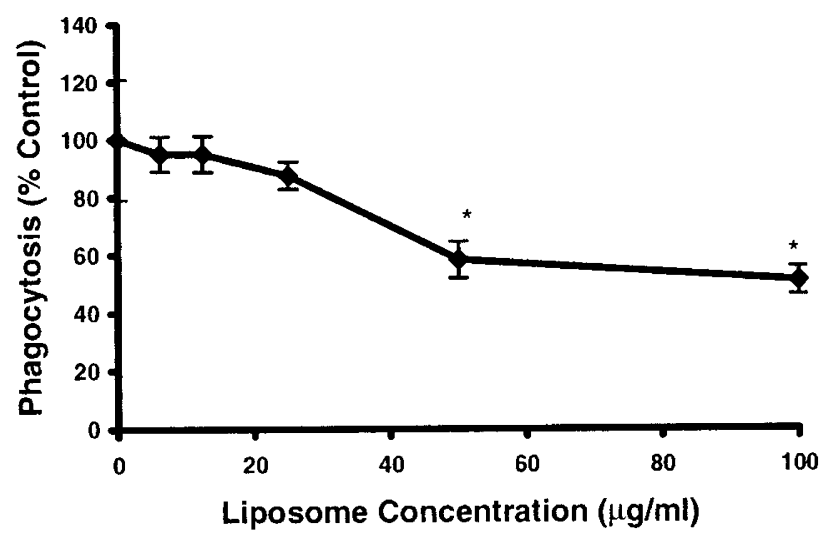

Figure 2. Survanta and surfactant-like liposomes inhibit SP-A-mediated stimulation of phagocytosis of $S$. pneumoniae by AM in a concentrationdependent manner. Increasing concentrations of $(A)$ Survanta or $(B)$ liposomes were incubated with AM, $25 \mu \mathrm{g} / \mathrm{mL}$ SP-A and FITC $S$. pneumoniae in DPBS $+0.9 \% \mathrm{CaCl}_{2}+0.1 \% \mathrm{BSA}$. The analyses were performed and data expressed as described for Figure 1. Asterisks indicate points that are significantly different $(p \leq 0.01)$ from the control (SP-A alone).

Table 3. Effect of Survanta on SP-A-mediated stimulation of phagocytosis of $S$. pneumoniae by $A M$

\begin{tabular}{cc}
\hline $\begin{array}{c}\text { Survanta } \\
(\mu \mathrm{g} / \mathrm{mL})\end{array}$ & $25 \mu \mathrm{g} \mathrm{SP}-\mathrm{A} / \mathrm{mL}$ \\
\hline 0 & $433 \pm 91.4 \% *$ \\
6.25 & $411.5 \pm 92.4 \% *$ \\
12.5 & $405.2 \pm 82.5 \% *$ \\
25 & $294 \pm 85.7 \%$ \\
50 & $295 \pm 81.8 \%$ \\
100 & $180.2 \pm 53.4 \%$ \\
\hline
\end{tabular}

Control (no Survanta or SP-A) phagocytosis is set at $100 \%$; values are expressed as percent control (no SP-A). AM were incubated at $37^{\circ} \mathrm{C}$ for $1 \mathrm{~h}$ in phagocytosis buffer with FITC S. pneumoniae and varying concentrations of Survanta in the presence of $25 \mu \mathrm{g} / \mathrm{mL}$ of SP-A. Extracellular fluorescence was quenched by the addition of trypan blue. Phagocytosis was measured by FACS analysis. Results are mean \pm SEM for at least three experiments. * Significantly greater than control $(\mathrm{p} \leq 0.05)$.

percentage of cells with associated bacteria decreased from control at $100 \%$ to $67.1 \pm 10.8 \%(p=0.019)$ and $67.3 \pm 9.1 \%$ $(p=0.022)$ when exposed to 150 and $250 \mu \mathrm{g} / \mathrm{mL}$ of liposomes, respectively. In both cases, the level of bacterial association with AM returned toward control as individual samples

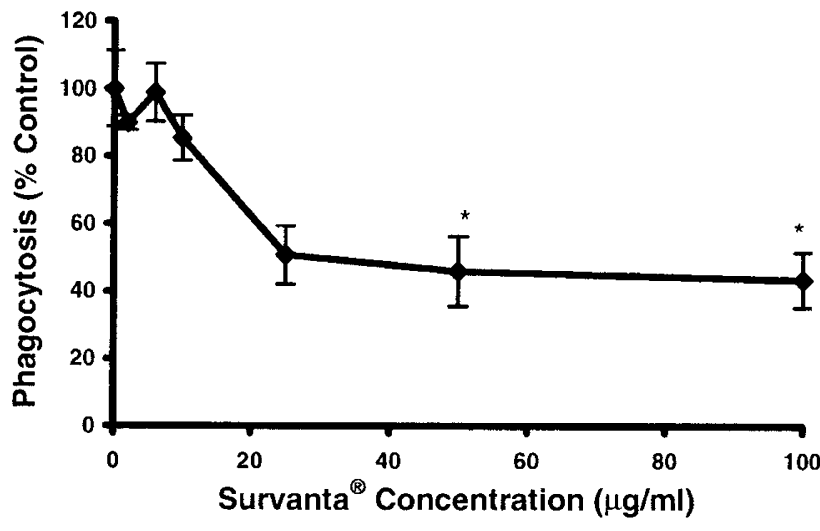

Figure 3. Survanta inhibits phagocytosis of SP-A-opsonized S. pneumoniae by $\mathrm{AM}$ in a concentration-dependent manner. FITC $S$. pneumoniae were opsonized with $25 \mu \mathrm{g} / \mathrm{mL}$ SP-A before incubation with AM and increasing concentrations of Survanta in DPBS $+0.9 \mathrm{mM} \mathrm{CaCl}_{2}+0.1 \%$ BSA. The analyses were performed and data expressed as described for Figure 1. Asterisks indicate points that are significantly different $(p<0.03)$ from the control.

of AM were exposed to decreasing concentrations of Survanta or liposomes. A representative experiment in which cell association is expressed as percent FITC-positive cells is shown in Table 5 .

Association of GBS with AM increases when exposed to Survanta or surfactant-like liposomes in the presence of $S P-A$ compared with the absence of SP-A. We demonstrate that $25 \mu \mathrm{g} / \mathrm{mL}$ SP-A significantly increases the association of GBS with AM. The percentage of cells with associated FITC GBS rose significantly from the control value of $100 \%$ to 203.1 $\pm 30.3 \%(p=0.007)$ and $229.9 \pm 32.8 \%(p=0.003)$ in the presence of $25 \mu \mathrm{g} / \mathrm{mL}$ of SP-A as seen in Tables 4 and 5 , respectively. At all concentrations of Survanta (Table 6) and liposomes (Table 7) tested, the presence of SP-A resulted in increased levels of association between bacteria and AM, with most reaching statistical significance $(p<0.05)$ as indicated by an asterisk.

\section{DISCUSSION}

Surfactant replacement therapies, which contain lipids and surfactant proteins $\mathrm{B}$ and $\mathrm{C}$, have dramatically reduced mortality due to the elevated surface tension in the lungs of infants with RDS. However, little is known about the roles surfactant deficiency and surfactant replacement therapy play in the immunity of the premature lung. We hypothesized that Survanta and surfactant-like liposomes would affect the abilities of AM to associate with and phagocytose bacteria and of SP-A to mediate the functions of AM in vitro. SP-A, although not required for the surface tension-lowering properties of natural surfactant (4), has been found to mediate host defense functions of AM (5-12). In animal studies, a deficiency of SP-A has resulted in an increased susceptibility to infection (13) with recovery of bacterial phagocytosis after exogenous SP-A therapy (5). In RDS, there is a deficiency of pulmonary surfactant and SP-A levels have been found to be low (31-34). It is not known whether SP-A deficiency results in any clinical com- 


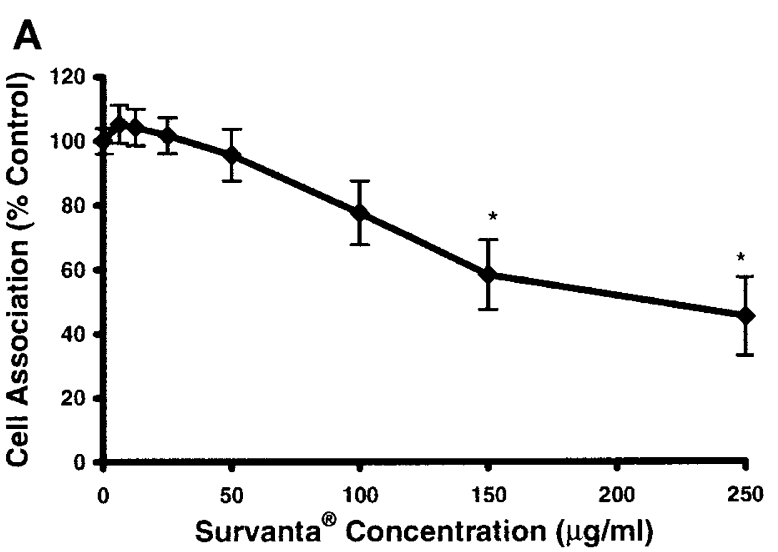

B

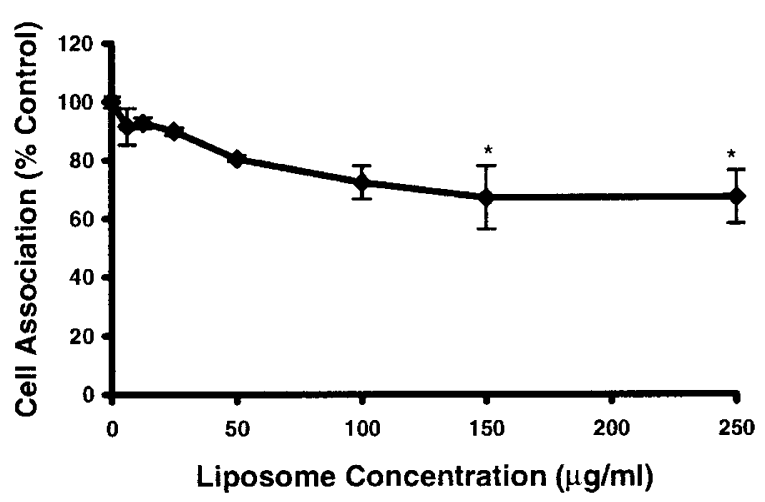

Figure 4. SP-A-mediated association of GBS with AM is inhibited by Survanta and surfactant-like liposomes in a concentration-dependent manner. Increasing concentrations of either $(A)$ Survanta or $(B)$ liposomes were incubated with AM, $25 \mu \mathrm{g} / \mathrm{mL}$ SP-A and FITC GBS in DPBS $+0.9 \% \mathrm{CaCl}_{2}+$ $0.1 \%$ BSA. Cell association was measured by FACS analysis. Data are expressed as a percent of the control condition in which no Survanta or liposomes were added and represent the mean \pm SEM for three experiments. Asterisks indicate points that are significantly different $(p \leq 0.03)$ from the control.

promise for infants or if its activity is modulated by the delivery of surfactant replacement.

In this study, we presented AM with S. pneumoniae in an in vitro phagocytosis assay. We found that increasing the concentration of lipids in our assay resulted in uptake of fewer bacteria by AM with statistical significance noted at 100 $\mu \mathrm{g} / \mathrm{mL}$ of Survanta. In addition, we studied the influence of SP-A on the interactions of S. pneumoniae and GBS with AM in the presence of varying concentrations of Survanta and surfactant-like liposomes. We found that SP-A-mediated phagocytosis of $S$. pneumoniae by AM was decreased significantly when exposed to the higher concentrations of Survanta and surfactant-like liposomes tested. We proposed that the lipids could be interfering with the binding of SP-A to the bacteria before uptake by AM. To examine this possibility, we opsonized the bacteria with SP-A before exposure to AM and Survanta without any significant change in our results. This finding does not exclude the notion that lipids may interfere with SP-A binding to bacteria but does indicate that there must be at least another mechanism by which they are acting as well.
Table 4. Effect of surfactant-like liposomes on SP-A-stimulated phagocytosis of $S$. pneumoniae by $A M$

\begin{tabular}{cc}
\hline $\begin{array}{c}\text { Liposomes } \\
(\mu \mathrm{g} / \mathrm{mL})\end{array}$ & $25 \mu \mathrm{g} \mathrm{SP}-\mathrm{A} / \mathrm{mL}$ \\
\hline 0 & $302.8 \pm 28.8 \% *$ \\
6.25 & $284.9 \pm 15.4 \% *$ \\
12.5 & $286 \pm 25.9 \%^{*}$ \\
25 & $266.2 \pm 34.1 \% *$ \\
50 & $180.1 \pm 34.4 \%$ \\
100 & $156.8 \pm 28.1 \%$ \\
\hline
\end{tabular}

Phagocytosis for the control condition (no liposomes or SP-A) is set at $100 \%$; values shown represent percent of control. AM were incubated at $37^{\circ} \mathrm{C}$ for $1 \mathrm{~h}$ in phagocytosis buffer with FITC S. pneumoniae and varying concentrations of liposomes in the presence of $25 \mu \mathrm{g} / \mathrm{mL}$ of SP-A. Extracellular fluorescence was quenched by the addition of trypan blue. Phagocytosis was measured by FACS analysis. Results are mean \pm SEM for three experiments. * Significantly greater than control $(\mathrm{p}<0.01)$.

We speculate that the bacteria may experience competition as the concentration of lipids is increased due to the fact that AM are known to ingest surfactant lipids $(17,21)$. In the case of GBS, we found that both Survanta and surfactant-like liposomes in the higher concentrations tested decreased the ability of SP-A to mediate the association of bacteria to AM. Despite our findings that SP-A-mediated host defense mechanisms of $\mathrm{AM}$ are hindered in the presence of lipids in vitro, it is important to note that the presence of SP-A almost always resulted in overall higher levels of phagocytosis and cell association when compared with the absence of SP-A.

Surfactant exists in the alveoli as a monomolecular film at the air-liquid interface. The true composition of this film is technically impossible to sample in situ; however, the proteins are thought to comprise a small, albeit critical, portion. Surfactant is constantly in a state of flux, undergoing production, secretion, degradation, and recycling throughout the alveoli, a process in which AM are a key component (35). Due to the continually changing nature of surfactant, it is likely that there are regional differences throughout the lung in both its lipid:protein ratio and lipid exposure to AM. Treatment doses of Survanta used clinically are $100 \mathrm{mg} / \mathrm{kg}$ per dose into the large airways, a portion of which reaches the alveoli to reduce surface tension. Survanta and lipid concentrations in the current study were limited to a maximum of $250 \mu \mathrm{g} / \mathrm{mL}$ in order to wash AM and remove excess bacteria without difficulty. SP-A was used at a concentration of $25 \mu \mathrm{g} / \mathrm{mL}$, as this has been shown to enhance phagocytosis in similar studies $(8,11$, 12). It is estimated that the SP-A concentration in the rat lung is in the range of $0.3-1.8 \mathrm{mg} / \mathrm{mL}$ (36); therefore, we believe that the current study utilizes lower concentrations of both the lipid and protein components of surfactant such that their ratio still falls within reason. We elected to challenge AM with many organisms in the current study. As our hypothesis stated that phagocytosis would be inhibited by the presence of Survanta and lipids, we wanted to ensure that low bacterial numbers would not influence our results. Although we cannot truly sample surfactant in situ, we believe our conditions reasonably represent interactions that may take place within alveoli in vivo.

Optimal functioning of the host defense system of the lung may be dependent on a critical balance between the protein and 
Table 5. Survanta inhibits SP-A-mediated association of GBS with AM

\begin{tabular}{cccccccc}
\hline \multicolumn{7}{c}{ Survanta concentration $(\mu \mathrm{g} / \mathrm{mL})$} \\
\cline { 2 - 5 } & 6.25 & 12.5 & 25 & 50 & 100 & 150 & 250 \\
\hline $86.9 \%$ & $85.0 \%$ & $84.2 \%$ & $81.2 \%$ & $73.0 \%$ & $50.6 \%$ & $44.4 \%$ & $30.7 \%$ \\
\hline
\end{tabular}

AM were incubated at $37^{\circ} \mathrm{C}$ for $1 \mathrm{~h}$ in phagocytosis buffer with FITC GBS and varying concentrations of Survanta in the presence of $25 \mu \mathrm{g} / \mathrm{mL}$ of SP-A. Cell association was measured by FACS analysis. Percentages shown are for FITC-positive cells of one representative experiment.

Table 6. Effect of Survanta on the association of $G B S$ with $A M$ in the presence and absence of $S P-A$

\begin{tabular}{ccc}
\hline $\begin{array}{c}\text { Survanta } \\
(\mu \mathrm{g} / \mathrm{mL})\end{array}$ & No SP-A & $25 \mu \mathrm{g} \mathrm{SP}-\mathrm{A} / \mathrm{mL}$ \\
\hline 0 & $100 \%$ & $203.1 \pm 30.3 \% *$ \\
6.25 & $95.3 \pm 7.4 \%$ & $178.8 \pm 12.2 \% *$ \\
12.5 & $94 \pm 9.2 \%$ & $177.1 \pm 12.1 \% *$ \\
25 & $95.7 \pm 6.4 \%$ & $172.5 \pm 10.5 \% *$ \\
50 & $93 \pm 7.4 \%$ & $161.6 \pm 9 \%^{*}$ \\
100 & $86.2 \pm 11.5 \%$ & $129.7 \pm 5.6 \% *$ \\
150 & $80.2 \pm 10.6 \%$ & $125.5 \pm 9.9 \% *$ \\
250 & $76.2 \pm 11.6 \%$ & $93.8 \pm 5.8 \%$ \\
\hline
\end{tabular}

Values are expressed as a percent of the association in the control condition (no Survanta or SP-A), which is set at $100 \%$. AM were incubated at $37^{\circ} \mathrm{C}$ for $1 \mathrm{~h}$ in phagocytosis buffer with FITC GBS and varying concentrations of Survanta in the presence and absence of $25 \mu \mathrm{g} / \mathrm{mL}$ of SP-A. Cell association was measured by FACS analysis. Results are mean \pm SEM for at least three experiments. * Significantly greater than the corresponding Survanta concentration without SP-A $(\mathrm{p}<0.05)$.

Table 7. Effect of surfactant-like liposomes on the association of $G B S$ with $A M$ in the presence and absence of $S P-A$

\begin{tabular}{ccl}
\hline $\begin{array}{c}\text { Liposomes } \\
(\mu \mathrm{g} / \mathrm{mL})\end{array}$ & No SP-A & $25 \mu \mathrm{g} \mathrm{SP}-\mathrm{A} / \mathrm{mL}$ \\
\hline 0 & $100 \%$ & $229.9 \pm 32.8 \% *$ \\
6.25 & $94.4 \pm 0.9 \%$ & $200.6 \pm 26.7 \% *$ \\
12.5 & $102.7 \pm 11 \%$ & $207.4 \pm 38.6 \%$ \\
25 & $103.6 \pm 12.8 \%$ & $201.2 \pm 37.9 \%$ \\
50 & $78.4 \pm 5.4 \%$ & $180.9 \pm 36 \% *$ \\
100 & $71.5 \pm 4.8 \%$ & $158.5 \pm 21.9 \% *$ \\
150 & $91.2 \pm 8.2 \%$ & $147.6 \pm 22 \%$ \\
250 & $73.3 \pm 5.8 \%$ & $148.9 \pm 21.1 \% *$ \\
\hline
\end{tabular}

Values are expressed as a percent of the association in the control condition (no liposomes or SP-A), which is set at $100 \%$. AM were incubated at $37^{\circ} \mathrm{C}$ for $1 \mathrm{~h}$ in phagocytosis buffer with FITC GBS and varying concentrations of liposomes in the presence and absence of $25 \mu \mathrm{g} / \mathrm{mL}$ of SP-A. Cell association was measured by FACS analysis. Results are mean \pm SEM for at least three experiments. * Significantly greater than the corresponding liposome concentration without SP-A $(\mathrm{p}<0.05)$.

lipid fractions of surfactant. The AM has been shown to ingest lipids $(17,21)$, which may be responsible for suppressing the oxidative burst of AM (24) as well as hindering its chemotactic responses (23) and pathogen killing $(22,23)$. Kremlev et al. (37-39) have shown that immune cell functions can be modulated by a balance between SP-A and surfactant lipids. They demonstrated that SP-A increases cell surface marker expression in a monocytic cell line (37), augments TNF- $\alpha$ secretion by splenocytes (38), and stimulates mitogen-induced lymphocyte proliferation (39). SP-A-induced increases were inhibited by surfactant lipids, yet maintained under certain conditions by modifying the SP-A:lipid ratio. Stamme and Wright (40) reported that SP-A enhances the binding and deacylation of lipopolysaccharide by AM, and this effect was retained in the presence of surfactant lipids. These studies, in addition to ours, provide evidence that SP-A can continue to mediate immune functions in the presence of lipids when the protein:lipid ratio is optimized.

This study provides insight into how the presence of Survanta or similar liposomes may affect functions of AM in the presence and absence of SP-A. In the newborn premature infant, it can be difficult to distinguish RDS from bacterial pneumonia $(25,26)$; for that reason, we have been interested in how surfactant replacement therapy might affect infants fighting an active pulmonary infection. Additionally, as a result of the evidence provided by LeVine et al. (13) demonstrating an increase in susceptibility to infection in SP-A-deficient mice, we wonder if surfactant-deficient premature infants would benefit from exogenous SP-A as in the LeVine et al. (5) follow-up study. We felt that it was first important to know whether or not SP-A could continue to mediate immune functions in the presence of a surfactant replacement therapy such as Survanta. We believe this study demonstrates that SP-A does retain this important function in vitro.

Acknowledgments. The authors thank Mike Cook and Lynn Martinek of the Duke Cancer Center for their assistance with FACS analysis.

\section{REFERENCES}

1. Avery M, Mead J 1959 Surface properties in relation to atelectasis and hyaline membrane disease. Am Med Assoc J Dis Child 97:517-523

2. Fujiwara T, Maeta H, Chida S, Morita T, Watabe Y, Abe T 1980 Artificial surfactant therapy in hyaline-membrane disease. Lancet 1:55-59

3. Auten RL, Watkins RH, Shapiro DL, Horowitz S 1990 Surfactant apoprotein A (SP-A) is synthesized in airway cells. Am J Respir Cell Mol Biol 3:491-496

4. Korfhagen TR, Bruno MD, Ross GF, Huelsman KM, Ikegami M, Jobe AH, Wert SE, Stripp BR, Morris RE, Glasser SW, Bachurski CJ, Iwamoto HS, Whitsett JA 1996 Altered surfactant function and structure in SP-A gene targeted mice. Proc Natl Acad Sci USA 93:9594-9599

5. LeVine AM, Kurak KE, Wright JR, Watford WT, Bruno MD, Ross GF, Whitsett JA, Korfhagen TR 1999 Surfactant protein-A binds group B streptococcus enhancing phagocytosis and clearance from lungs of surfactant protein-A-deficient mice. Am J Respir Cell Mol Biol 20:279-286

6. Manz-Keinke H, Plattner H, Schlepper-Schafer J 1992 Lung surfactant protein A (SP-A) enhances serum-independent phagocytosis of bacteria by alveolar macrophages. Eur J Cell Biol 57:95-100

7. Pikaar JC, Voorhout WF, van Golde LMG, Verhoef J, van Strijp JAG, van Iwaarden JF 1995 Opsonic activities of surfactant proteins A and D in phagocytosis of gram-negative bacteria by alveolar macrophages. J Infect Dis 172:481-489

8. Tino MJ, Wright JR 1996 Surfactant protein A stimulates phagocytosis of specific pulmonary pathogens by alveolar macrophages. Am J Physiol 14:L677-L688

9. van Iwaarden F, Welmers B, Verhoef J, Haagsman HP, van Golde LM 1990 Pulmonary surfactant protein A enhances the host-defense mechanism of rat alveolar macrophages. Am J Respir Cell Mol Biol 2:91-98

10. Wright JR, Youmans DC 1993 Pulmonary surfactant protein-A stimulates chemotaxis of alveolar macrophage. Am J Physiol 264:L338-L344

11. Schagat TL, Tino MJ, Wright JR 1999 Regulation of protein phosphorylation and pathogen phagocytosis by surfactant protein A. Infect Immun 67:4693-4699

12. Mariencheck WI, Savov J, Dong Q, Tino MJ, Wright JR 1999 Surfactant protein A enhances alveolar macrophage phagocytosis of a live, mucoid strain of $P$. aeruginosa. Am J Physiol 277:L777-L786 
13. LeVine AM, Bruno MD, Huelsman KM, Ross GF, Whitsett JA, Korfhagen TR 1997 Surfactant protein-A deficient mice are susceptible to group B streptococcal infection. J Immunol 158:4336-4340

14. Borron P, McIntosh JC, Korfhagen TR, Whitsett JA, Taylor J, Wright JR 2000 Surfactant-associated protein A inhibits LPS-induced cytokine and nitric oxide production in vivo. Am J Physiol 278:L840-L847

15. Green GM, Kass EH 1964 The role of the alveolar macrophage in the clearance of bacteria from the lung. J Exp Med 119:167-176

16. Alenghat E, Esterly JR 1984 Alveolar macrophages in perinatal infants. Pediatrics 74:221-223

17. Zeligs BJ, Nerurkar LS, Bellanti JA, Zeligs JD 1977 Maturation of the rabbit alveolar macrophage during animal development. I. Perinatal influx into alveoli and ultrastructural differentiation. Pediatr Res 11:197-208

18. Evans MJ, Sherman MP, Campbell LA, Shami SG 1987 Proliferation of pulmonary alveolar macrophages during postnatal development of rabbit lungs. Am Rev Respir Dis $136: 384-387$

19. Sherman MP, Evans MJ, Campbell LA 1988 Prevention of pulmonary alveolar macrophage proliferation in newborn rabbits by hyperoxia. J Pediatr 112:782-786

20. Hall SL, Sherman MP 1992 Intrapulmonary bacterial clearance of type III group B streptococcus is reduced in preterm compared with term rabbits and occurs independent of antibody. Am Rev Respir Dis 145:1172-1177

21. Nerurkar LS, Zeligs BJ, Bellanti JA 2071977 Maturation of the rabbit alveolar macrophage during animal development. II. Biochemical and enzymatic studies. Pediatr Res 11:1202-1207

22. Sherman MP, D'Ambola JB, Aeberhard EE, Barrett CT 1988 Surfactant therapy of newborn rabbits impairs lung macrophage bactericidal activity. J Appl Physiol 65:137-145

23. Zeligs BJ, Nerurkar LS, Bellanti JA 1984 Chemotactic and candidacidal responses of rabbit alveolar macrophages during postnatal development and the modulating roles of surfactant in these responses. Infect Immun 44:379-385

24. Hayakawa H, Myrvik QN, St Clair RW 1989 Pulmonary surfactant inhibits priming of rabbit alveolar macrophage. Evidence that surfactant suppresses the oxidative burst of alveolar macrophages in infant rabbits. Am Rev Respir Dis 140:1390-1397

25. Sherman MP, Goetzman BW, Ahlfors CE, Wennberg RP 1980 Tracheal aspiration and its clinical correlates in the diagnosis of congenital pneumonia. Pediatrics 65:258-263

26. Ablow RC, Driscoll SG, Effmann EL, Gross I, Jolles CJ, Uauy R, Warshaw JB 1976 A comparison of early-onset group B streptococcal neonatal infection and the respiratory-distress syndrome of the newborn. N Engl J Med 294:65-70
27. Herting E, Gefeller O, Land M, van Sonderen L, Harms K, Robertson B 2000 Surfactant treatment of neonates with respiratory failure and group B streptococcal infection. Pediatrics 106:957-964

28. Wright JR, Wager RE, Hawgood S, Dobbs L, Clements JA 1987 Surfactant apoprotein $M_{\mathrm{r}}=26,000-36,000$ enhances uptake of liposomes by type II cells. J Biol Chem 262:2888-2894

29. Tino MJ, Wright JR 1999 Surfactant proteins A and D specifically stimulate directed actin-based responses in alveolar macrophages. Am J Physiol 276:L164-L174

30. Dong Q, Wright JR 1998 Degradation of surfactant protein D by alveolar macrophages. Am J Physiol 18:L97-L105

31. Chida S, Phelps DS, Cordle C, Soll R, Floros J, Taeusch HW 1988 Surfactantassociated proteins in tracheal aspirates of infants with respiratory distress syndrome after surfactant therapy. Am Rev Respir Dis 137:943-947

32. Gerdes J, Whitsett J, Long W 1992 Elastase activity and surfactant protein concentration in tracheal aspirates from neonates receiving synthetic surfactant. J Pediatr 120:S34-S39

33. Hallman M, Merritt TA, Akino T, Bry K 1991 Surfactant protein A, phosphatidylcholine, and surfactant inhibitors in epithelial lining fluid. Correlation with surface activity, severity of respiratory distress syndrome, and outcome in small premature infants. Am Rev Respir Dis 144:1376-1384

34. Moya FR, Montes HF, Thomas VL, Mouzinho AM, Smith JF, Rosenfeld CR 1994 Surfactant protein A and saturated phosphatidylcholine in respiratory distress syndrome. Am J Respir Crit Care Med 150:1672-1677

35. Wright JR, Dobbs LG 1991 Regulation of pulmonary surfactant secretion and clearance. In: Hoffman JF (ed) Annual Review of Physiology. Annual Reviews, Palo Alto, pp 395-414

36. Wright JR 1997 Immunomodulatory functions of surfactant. Physiol Rev 77:931-962

37. Kremlev SG, Phelps DS 1997 Effect of SP-A and surfactant lipids on expression of cell surface markers in the THP-1 monocytic cell line. Am J Physiol 272:L1070L1077

38. Kremlev SG, Phelps DS 1994 Surfactant protein A stimulation of inflammatory cytokine and immunoglobulin production. Am J Physiol 267:L712-L719

39. Kremlev SG, Umstead TM, Phelps DS 1994 Effects of surfactant protein A and surfactant lipids on lymphocyte proliferation in vitro. Am J Physiol 267:L357L364

40. Stamme C, Wright JR 1999 Surfactant protein A enhances the binding and deacylation of E. coli LPS by alveolar macrophages. Am J Physiol 276:L540-L547 